\title{
Impact of Teamwork on Organizational Productivity in Nepalese Commercial Banks
}

\begin{abstract}
Teamwork is a critical component of team performance and requires an explanation of how a team behaves and it has the ability to enable the members of the team to have a higher level of emotional security, self-confidence and the ability to plan and decide with others positively. However, the benefits of teamwork for the employees are often more abstract and difficult to distinguish that may hamper organizational productivity. This study is an endeavor to extend the literature of impact on teamwork on organizational productivity in commercial banks. This paper attempts to examine the impact of teamwork on organizational productivity in Nepalese commercial banks. Structured questionnaires were distributed to 500 respondents of 27 Nepalese commercial banks but out of them only 350 responses are collected and are used for analysis. Descriptive and casual comparative research design are used to determine the relationship of organizational productivity (dependent variable) with independent variables (teamwork, team trust, working environment, training and development, and esprit de corps). Descriptive statistics and multiple regression models have been used to analyze the data. Organizational productivity is positively correlated with all independent variables and regression results exhibit significant and positive beta coefficients. It is observed that working environment is the most powerful factor for organizational productivity and employees' satisfaction and training and development is the least influencing factor among all factors. Nepalese commercial banks also take into consideration team trust, teamwork, and espirit de corps because these factors have positive impact on organizational productivity. Nepalese commercial banks should focus on increase in prompt response to the team trust, appropriate training and development, better working environment, and proper teamwork to increase productivity.
\end{abstract}

Keywords: Team work, team trust, working environment, training and development, esprit de corps

Paper Type: Research paper

\section{Introduction}

Organizational productivity, the capacity of an organization to produce expected output by spending low unit of inputs, is a researchable issue to academicians and professionals for last few decades. Productivity is the increased functional and organizational performance including quality (Dorgan, 1994) and it can achieve by using minimum efforts. Several

\footnotetext{
* Lecturer, Shanker Dev Campus, Tribhuvan University.

E-mail:mailtoadhikarisir@gmail.com
} 
researchers interested to find how the interaction of environment, technology, organization, and people variables affects organizational productivity (Thompson, 1967; Lawrence \& Lorsch, 1969; Scott, 1987). Teamwork, a group work with a common purpose for the achievement of goals, focuses more on the shared behaviors (i.e., what team members do), attitudes (i.e., what team members feel or believe), and cognitions (i.e., what team members think or know) that are necessary for teams to accomplish the tasks (Morgan, Ben, Eduardo, \& Albert, 1994). Understanding the impact of teamwork on performance is important because teamwork is viewed by some researchers as one of the key driving forces for improving a firm's performance (Jones, Richard, Paul, Sloane, \& Peter, 2007; Agrawal \& Adjirackor, 2016). Mbinya (2013) argued that most of the multinational organizations have embraced the spirit of teamwork which have enable them to survive in the competitive market environment. There is significant impact of team building on organizational productivity and it is the way to achieve success in organization (Ulabor, Akande, \& Abiodun, 2020).

Team trust, foundation for effective team work, is positive related with team performance (Mickan, \& Sylvia, 2000) and trust provides an atmosphere for the team members where members can discuss their mistakes, accept criticism and freely express their feelings so this leads to more synergy (Edmondson, 1999). Similarly, Hamonangan, Asmawi, and Widodo (2020) stated that trust has positive direct influence to organizational commitment. Working environment affects employees' morale, productivity and engagement both positively and negatively. A decent working environment is a condition where individuals can do their jobs in an ideal, secure, healthy, and comfort way (Sedarmayanti, 2003). Nepal (2016) concluded that the working condition is the major determining variable for organizational productivity. An organization's physical environment particularly its layout and design can impact employee behavior in the workplace (McGuire \& McLaren, 2009). Raziq and Maulabakhsh (2015) found a positive relationship between working environment and employee job motivation with some brief prospects that the businesses need to realize the importance of good working environment for maximizing the level of job satisfaction. Likewise, work environment plays important role to produce and raise worker productivity in line with the employee's ability and social network (Rasool, Maqbool, Samma, Zhao, \& Anjum, 2019).

Training and development is concerned with organizational activities aimed at bettering the performance of employees in organizational setting. Sims (2002) argued that training focuses on existing works while development prepares employees for possible future works. There is significant relationship between training and development and firm performance (Nikandrou, \& Tsachouridi, 2015; Chaudhary \& Sharma, 2012; Ahmad \& Din, 2009). Esprit de corps, a feeling of pride and mutual loyalty shared by the members of a group, is the key for success in the organization (Reisel, Chia, \& Maloes, 2005) and significant relationship with firm performance (Manzoor, Vllah, Hussain, \& Ahmad, 2011; Boyt, Lusch, Naylor, 2001), however, Tirmizi and Shahzad (2009) revealed that most of the employees pursue their individual tasks rather than group. Similarly, the study conducted in Korean hospitals indicated that esprit de corps has been negatively recognized by physicians (Hwang \& Chang, 2009). Moreover, research has been done regarding the issues in western context, however, 
there are very few research has been done in the context of Nepalese banking sector. Hence, this paper attempts to examine linkage of teamwork effect with organizational productivity of Nepalese commercial banks. The next section of this paper is research hypotheses that are used in this study following by research methodology adopted in this paper in section three. Similarly, section four describes the results and discussions and final section concludes the paper.

\section{Research Hypotheses}

This paper has set the following alternative hypotheses:

$H_{1}$ : There is a positive relationship between teamwork and the organizational productivity.

$H_{2}$ : There is a positive relationship between team trust and the organizational productivity.

$H_{3}$ : There is a positive relationship between working environment and the organizational productivity.

$\mathrm{H}_{4}$ : There is a positive relationship of training and development with the organizational productivity.

$H_{5}$ : There is a positive relationship of esprit de corps with the organizational productivity.

\section{Methodology}

Descriptive research design that reduces the data to manageable form has used to deal the fundamental issues associated with organizational productivity due to teamwork effect of commercial banks and has also used casual comparative research design to examine the relationship between teamwork and productivity. The required data are collected from 350 respondents of 27 commercial banks through structured questionnaire and the questionnaire is divided into two sections where first section is related to basic information of the respondents and second section is concerned with five point Likert type questions about the quality variables that affect organizational productivity which scale ranges from 1 (Strongly agree) to 5 (Strongly disagree). It is assumed that the organizational productivity depends on teamwork, team trust, working environment, training \& development and esprit de corps. Therefore, the model takes the following form:

Organizational productivity $=f$ (teamwork, team trust, working environment, training and development, esprit de corps).

This paper estimates regression model to examine the impact of teamwork on organizational productivity which is presented as:

$O P=a+\beta_{1} T W+\beta_{2} T T+\beta_{3} W E+\beta_{4} T D+\beta_{5} E C+\varepsilon_{i}$

Where, $\mathrm{OP}=$ Organizational productivity; $\mathrm{TW}=$ Teamwork, $\mathrm{TT}=$ Team trust; $\mathrm{WE}=$ Working environment, $\mathrm{TD}=$ Training and development, $\mathrm{EC}=$ Esprit de corps; $\alpha=$ constant term; $\beta_{1}, \beta_{2}$, $\beta_{3,} \beta_{4}, \beta_{5}=$ beta coefficients and $\varepsilon_{i}=$ error term. 


\section{Reliability Test}

Table 1 presents the results of value of Cronbach alpha for all selected variables where all values are greater than 0.70 which indicates the data gathered for primary data are reliable and valid.

Table 1:

Coefficient of Cronbach's alpha

\begin{tabular}{lcc}
\hline \multicolumn{1}{c}{ Variables } & Cronbach's alpha & No. of item \\
\hline Teamwork & 0.712 & 5 \\
Team trust & 0.762 & 5 \\
Working environment & 0.792 & 5 \\
Training \& development & 0.739 & 5 \\
Espirit de corps & 0.741 & \multicolumn{2}{c}{5} \\
Organizational productivity & 0.773 & 5 \\
Overall & 0.742 & 30 \\
\hline
\end{tabular}

\section{Results and Discussions \\ Descriptive analysis}

The mean value of teamwork ranges from minimum value of 1.387 to maximum value of 1.836 and the weighted average is 1.665 which reveals employees of banks are ready to do their work in team that increases the organizational productivity. Similarly, the mean value of team trust ranges from minimum value of 1.205 to maximum value of 1.676 and the weighted average is 1.513 which states trust in team is an essential component that effects organizational productivity. Likewise, the mean value of working environment ranges from minimum value of 1.181 to maximum value of 1.735 and the weighted average value is 1.469 that shows organizational productivity increases because of good working environment. Additionally, the mean value of training and development ranges from minimum value of 1.119 to maximum value of 1,636 and the weighted average is 1.498 that indicates training and development is essential for organizational productivity. Furthermore, the mean value of espirit de corps ranges from minimum value of 1.280 to maximum value of 2.123 and the weighted average is 1.627 that reveals espirit de corps possesses the positive impact on organizational productivity in Nepalese commercial banks. 
Correlation analysis

Table 2

\section{Correlation Matrix}

This table presents correlation coefficients between dependent variable (organizational productivity) and independent variables (teamwork, team trust, working environment, training and development, and espirit de corps).

\begin{tabular}{lcccccccr}
\hline Variables & Mean & SD & OP & TW & TT & WE & TD & EC \\
\hline OP & 1.279 & 0.326 & 1 & & & & & \\
TW & 1.665 & 0.244 & $0.198^{*}$ & 1 & & & & \\
TT & 1.513 & 0.290 & $0.201^{*}$ & $0.399^{*}$ & 1 & & & \\
WE & 1.469 & 0.262 & $0.553^{* *}$ & $0.222^{*}$ & $0.314^{* *}$ & 1 & & \\
TD & 1.498 & 0.243 & 0.081 & $0.321^{* *}$ & $0.301^{* *}$ & 0.167 & 1 & \\
EC & 1.627 & 0.376 & 0.111 & $0.324^{* *}$ & $0.223^{*}$ & 0.031 & $0.531^{* *}$ & 1 \\
\hline
\end{tabular}

Note *significant at $1 \%$ level

**significant at $5 \%$ level

Table 2 exhibits that organizational productivity is positively correlated with all independent variables that indicates increase in teamwork leads to increase in organizational productivity, increase in team trust leads higher organizational productivity maintaining better working environment in a firm leads to increase in organizational productivity, higher the training provided to the employees, better would lead the organizational productivity, espirit de corps leads higher productivity.

\section{Regression analysis}

\section{Table 3}

\section{Regression results}

This table presents regression results based on 350 observations by using ordinary linear regression model. The model is: $\mathrm{OP}=\alpha+\beta_{1} \mathrm{TW}+\beta_{2} \mathrm{TT}+\beta_{3} \mathrm{WE}+\beta_{4} \mathrm{TD}+\beta_{5} \mathrm{EC}+\varepsilon_{\mathrm{i}^{\prime}}$ where, $\mathrm{OP}=$ Organizational productivity; TW $=$ Teamwork, TT $=$ Team trust, $\mathrm{WE}=$ Working environment, $\mathrm{TD}=$ Training and development, $\mathrm{EC}=$ Esprit de corps, $\alpha=$ constant term; $\beta_{1}, \beta_{2}, \beta_{3}, \beta_{4}, \beta_{5}=$ beta coefficients and $\varepsilon_{\mathrm{i}}=$ error term. 


\begin{tabular}{|c|c|c|c|c|c|c|c|c|c|}
\hline \multirow[t]{2}{*}{ Model } & \multirow[t]{2}{*}{ Intercept } & \multicolumn{4}{|c|}{ Regression coefficients of } & \multirow[b]{2}{*}{$\mathrm{EC}$} & \multirow{2}{*}{$\begin{array}{c}\text { Adj. } \\
\mathrm{R}^{2}\end{array}$} & \multirow[t]{2}{*}{ SEE } & \multirow{2}{*}{$\begin{array}{c}\text { F- } \\
\text { Value }\end{array}$} \\
\hline & & TW & TT & WE & $\mathrm{TD}$ & & & & \\
\hline 1 & $\begin{array}{c}0.896 \\
(4.659)^{* *}\end{array}$ & $\begin{array}{c}0.291 \\
(2.223)^{*}\end{array}$ & & & & & 0.042 & 0.387 & 4.912 \\
\hline 2 & $\begin{array}{c}1.102 \\
(6.198)^{* *}\end{array}$ & & $\begin{array}{c}0.245 \\
(2.212)^{*}\end{array}$ & & & & 0.044 & 0.365 & 4.982 \\
\hline 3 & $\begin{array}{c}0.316 \\
(2.132)^{*}\end{array}$ & & & $\begin{array}{c}0.721 \\
(7.332)^{\star *}\end{array}$ & & & 0.318 & 0.303 & 53.421 \\
\hline 4 & $\begin{array}{c}1.324 \\
(6.201)^{* *}\end{array}$ & & & & $\begin{array}{c}0.121 \\
(0.869)\end{array}$ & & 0.001 & 0.389 & 0.901 \\
\hline 5 & $\begin{array}{c}1.632 \\
(11.124)^{* *}\end{array}$ & & & & & $\begin{array}{c}0.097 \\
(1.187)\end{array}$ & 0.002 & 0.387 & 1.421 \\
\hline 6 & $\begin{array}{c}0.901 \\
(3.811)^{* *}\end{array}$ & $\begin{array}{c}0.192 \\
(1.512)\end{array}$ & $\begin{array}{c}0.217 \\
(1.514)\end{array}$ & & & & 0.041 & 0.372 & 3.668 \\
\hline 7 & $\begin{array}{c}0.215 \\
(0.798)\end{array}$ & $\begin{array}{c}0.714 \\
(6.719)^{* *}\end{array}$ & $\begin{array}{c}0.116 \\
(0.941)\end{array}$ & $\begin{array}{c}0.00 \\
(0.001)\end{array}$ & & & 0.321 & 0.334 & 17.875 \\
\hline 8 & $\begin{array}{c}0.201 \\
(0.876)\end{array}$ & $\begin{array}{c}0.102 \\
(0.411)\end{array}$ & $\begin{array}{c}0.101 \\
(1.066)\end{array}$ & $\begin{array}{c}0.009 \\
(0.072)\end{array}$ & $\begin{array}{c}0.676 \\
(6.675)^{* *}\end{array}$ & & 0.342 & 0.301 & 13.445 \\
\hline 9 & $\begin{array}{c}0.315 \\
(1.165)\end{array}$ & $\begin{array}{c}0.114 \\
(0.651)\end{array}$ & $\begin{array}{c}0.197 \\
(1.428)\end{array}$ & $\begin{array}{c}0.015 \\
(0.158)\end{array}$ & $\begin{array}{c}0.631 \\
(6.468)^{* *}\end{array}$ & $\begin{array}{c}0.152 \\
(2.204)^{*}\end{array}$ & 0.376 & 0.317 & 12.245 \\
\hline
\end{tabular}

Notes:

Figures in parenthesis are t-values

The asterisk signs $\left({ }^{*}\right)$ and $\left({ }^{* *}\right)$ indicate that the results are significant at 1 percent and 5 percent level respectively.

\section{Dependent variable is organizational productivity}

Table 3 shows the value of intercept for teamwork is 0.896 which states if teamwork is zero then organizational productivity is 0.896 units. Studying organizational productivity with only one factor teamwork, one unit change in teamwork will the change organizational productivity by 0.291 .The value of adjusted $\mathrm{R}^{2} 0.042$ shows that 4.2 percent of organizational productivity is explained by teamwork and rest by other factors. Working environment has the highest impact on organizational productivity among all factors presented in this study that is it explains 31.8 percent change on organizational productivity. Similarly, the 
value of intercept for working environment is 0.721 that reveals one unit change on working environment will change organizational productivity by 0.721 units. Likewise, training and development has the lowest impact on organizational productivity that is it has explained organizational productivity by 0.121 . Further, the effect on organizational productivity is 37.6 percent by joint effect of all five factors and remaining is due to other factors.

Table 3 exhibits that teamwork has positive and significant beta coefficient that reveals it has positive impact on organizational productivity which is similar to the findings of Mingchang and Ya-Hsueh (2014). Similarly, positive and significant beta for team trust indicates team trust has positive impact on organizational productivity and it is consistent with the findings of Mickan and Sylvia (2000). Working environment has positive and significant beta that states it has positive impact on organizational productivity and this result is also same as the findings of Nepal (2016). Likewise, positive beta for training and development shows it has positive impact on organizational productivity and it is similar to findings of Nikandrou and Tsachourid (2015). Moreover, espirit de corps has positive beta that reveals it has positive impact on organizational productivity and this findings is consistent with the findings of Reisel et al. (2005).

\section{Conclusion}

It is observed that teamwork, team trust, training and development, working environment and espirit de corps affect organizational productivity. Of these factors, working environment is the most important factor. Employees are more satisfied with better working environment though they also take into consideration teamwork, team trust, training and development, and espirit de corps. Positive and significant correlation indicates that Nepalese commercial banks should focus on increase in prompt response to the team trust, appropriate training and development, better working environment, and proper teamwork to increase organizational productivity. 


\section{References}

Agrawal, S., \& Adjirackor, T. (2016). Impact of teamwork on organizational productivity in some selected basic schools in the ACCRA Metropolitan Assembly. European Journal of Business, Economics and Accountancy, 4(6), 40-52.

Ahmad, I., \& Din, S. (2009). Evaluating training and development. Gomal Journal of Medical Sciences, 7, 165-166.

Boyt, T. E., Lusch, R. F., \& Naylor, G. (2001). The role of professionalism in determining job satisfaction in professional services: A study of marketing researchers. Journal of Service Research, 3 (4), 321-330.

Chaudhary, N., \& Sharma, B. (2012). Impact of employee motivation on performance (productivity) in Private organization. International Journal of Business Trends and Technology, 2(4), 25-31.

Dorgan, C. E. (1994). Productivity link to the indoor environment estimated relative to ASHRAE 62-1989 proceedings of health buildings. Budapest, 461-472.

Edmondson, A. C. (1999). Psychological safety and learning behavior in work teams. Administrative Science Quarterly. 44(2), 350-383.

Hamonangan, I. D., Asmawi, M., \& Widodo, S. E. (2020). The effect of organizational culture, leadership style, and trust to organizational commitments of LP31 Polytechnic Jakarta lecturers. International Journal of Human Capital Management, 4(1), 16-25.

Hwang, J. I., \& Chang, H. (2009). Work climate perception and turnover intention among Korean Hospital Staff. International Nursing Review, 56 (1), 73-80.

Jones, A., Richard, B., Paul, D., Sloane, K., and Peter, F. (2007). Effectiveness of teambuilding in organization. Journal of Management, 5(3), 35-37.

Lawrence, P. R., \& Lorsch, J. W. (1969). Organization and environment. Boston, MA: Harvard Business School, Division of Research.

Manzoor, S. R., Vllah, H., Hussain, M., \& Ahmad, Z. M. (2011). Effect of teamwork on employee performance. International Journal of Learning and Development, 1 (1), 110-126.

Mbinya, M. E. (2013). Factors affecting teamwork in export processing zones in Kenya: $A$ Case of Indigo Garments Export Processing Zone LTD (Master's dissertation, Kenyatta University).

McGuire, D., \& McLaren, L. (2009). The impact of physical environment on employee commitment in call centres: The mediating role of employee well-being. Team Performance Management, 15(1/2), 35-48. 
Mickan, S., \& Sylvia, R. (2000). The organizational context for teamwork: Comparing health care and business literature. Australian Health Review, 23 (1), 179-192.

Mingchang, W., Ya-Hsueh, C. (2014). A factor analysis on teamwork performance: An empirical study of inter-instituted collaboration. European Journal of Educational Research, 55, 37-54.

Morgan, Jr., Ben, B., Eduardo, S., \& Albert, G. (1993). An analysis of team evolution and maturation. Journal of General Psychology, 120(July), 277-291.

Nepal, P. (2016). Relationship between job satisfaction and performance of Nepalese commercial banks. Nepalese Journal of Management Journal, 34(1), 487-516.

Nikandrou, I., \& Tsachouridi, I. (2015). Towards a better understanding of the buffering effects of organizational virtuousness' perceptions on employee outcomes. Management Decision, 53(8), 1823-1842.

Rasool, S. F., Maqbool, R., Samma, M., Zhao, Y., \& Anjum, A. (2019). Positioning depression as a critical factor in creating a toxic workplace environment for diminishing worker productivity. Sustainability, 11(9), 1-18.

Raziq, A., \& Maulabakhsh, R. (2015). Impact of working environment on job satisfaction. Procedia Economics and Finance, 23, 717-725.

Reisel, W. D., Chia, S. L., \& Maloles, C. M. (2005). Job insecurity spillover to key account management: Negative effect on performance, effectiveness, adaptiveness, and esprit de corps. Journal of Business and Psychology, 19(4), 483-503.

Scott, W. R. (1987). The adolescence of Institutional theory. Administrative Science Quarterly, 32(4), 493-511.

Sedarmayanti, A. (2003). Working procedures and work productivity an overview of aspects of ergonomics or the link between man and work environment. Bandung: Mandar Maju, 1(2), 67-80.

Sims, R. (2002). Organizational success through effective human resources management. Westport CT: Quorum Books

Thompson, J. D. (1967). Organizations in action: Social science bases of administrative theory. New York: McGraw-Hill.

Tirmizi, M. A., \& Shazad, M. H. S. (2009). Is it industry productive: A performance base investigation of IT sector firms operating in Pakistan? International Journal of Business management, 4(5), 207-221. 
Ulabor, E. A., Akande, S. O., \& Abiodun, O. B. (2020). Investing impacts of team -building and organizational leadership on corporate productivity: Case study of selected employees in Osun state Nigeria. Business, management, and Economics Research, 6(2), 21-29. 